\title{
Serpocaulon orosiense, a New Hybrid of Serpocaulon (Polypodiaceae) from Costa Rica
}

\author{
Alexander Francisco Rojas-Alvarado*, Lucía Barrantes-Calvo \\ Universidad Nacional de Costa Rica, Heredia, Costa Rica \\ Email: *alexander.rojas.alvarado@una.cr
}

How to cite this paper: Rojas-Alvarado, A.F. and Barrantes-Calvo, L. (2021) Serpocaulon orosiense, a New Hybrid of Serpocaulon (Polypodiaceae) from Costa Rica. Open Access Library Journal, 8: e8047. https://doi.org/10.4236/oalib.1108047

Received: October 3, 2021

Accepted: November 5, 2021

Published: November 8, 2021

Copyright $\odot 2021$ by author(s) and Open Access Library Inc.

This work is licensed under the Creative Commons Attribution International License (CC BY 4.0).

http://creativecommons.org/licenses/by/4.0/ (c) (i) Open Access

\begin{abstract}
Four hybrids between Serpocaulon species have been described, one of them $S$. $\times$ sessilipinnum was the only known hybrid between two different clades proposed by Smith et al. In this work, a new hybrid $S . \times$ orosiense is described, being the second known hybrid between clades: 1) Serpocaulon loriceum and 2) S. fraxinifolium. The detailed study of the intermediate morphology of the characters of the new taxon and their progenitors were made by light microscopy with a Motic Instruments brand binocular stereoscope, Model SMZ-171-BLED and photographs of the spores with a Motic brand binocular microscope, model BA210E. The new nothotaxon has intermediate characters between $S$. fraxinifolium and $S$. loriceum as size of the frond; shape, division and apex of the leaf blade; shape, broad, apex and number of pinnae; and number of series of areoles and sori. As result and conclusion, a new nothotaxon with intermediate morphology between two progenitors is discovered between different clades within the genus Serpocaulon.
\end{abstract}

\section{Subject Areas \\ Biology, Botany, Taxonomy}

\section{Keywords}

Ferns, Nothotaxon, Polypodiopsida, Serpocaulon fraxinifolium, S. loriceum

\section{Introduction}

Serpocaulon A.R. Sm. is a segregated genus of Polypodium L. [1]. Many of the species were initially described in Goniophlebium (Blume) C. Presl, a genus of about 25 species occurring from India, southeast and eastern Asia, the Himalayan region, and Malaysia to Australasia, Melanesia, Samoa, and Micronesia [2]. However, molecular phylogenetic analysis of Schneider et al. [3] demon- 
strated that Serpocaulon is nested in a predominantly New World clade, containing the genera Microgramma C. Presl, Campyloneurum C. Presl, Pleopeltis Humb. \& Bompl. ex Willd., Pecluma M.G. Price and Polypodium s.s., as well as the Pantropical grammitid clade [1].

Serpocaulon is defined as having commonly anastomosing veins, chevronshaped areoles, 1 - 10 areole series between the costa and pinnae margin, excurrent veinlets in the areoles, as well as a generally long-creeping, branched rhizome, with peltate clathrate rhizome scales (at least in the central or basal part). It also has monolete spores with verrucate and occasionally winged ornamentation [4] [5] [6].

Serpocaulon has a Neotropical distribution [1]. Of the 40 - 45 species assigned to Serpocaulon, 14 have distributions restricted to the West Indies, Central America and southern Mexico; two are confined to the West Indies, North America, Central America and northern Colombia; and 26 - 28 are located in South America [1], with diversification centers in the Cordillera Central of Colombia [7] and the Brazilian Atlantic Forest [8].

Smith et al. [1] divided the genus into four informal groups (confirmed by Sanín (2006)): 1) Serpocaulon loriceum, 2) S. fraxinifolium, 3) S. subandinum and 4) $S$. lasiopus. However, the new hybrid described here is between $S$. loriceum (group 1) and $S$. fraxinifolium (group 2).

In Serpocaulon, several new hybrids have been described in the last decade, for example: $S . \times$ pubescens (Rosenst.) Schwartsb. \& A.R. Sm. [8], $S . \times$ sessilipinnum A. Rojas \& J.M. Chaves [9], S. $\times$ manizalense D. Sanín \& Torrez [10] and $S . \times$ rojasianum J.M. Chaves, R.C. Moran \& F. Oviedo [11].

The purpose of the second hybrid described here between a pinnatisect species as $S$. loriceum (group 1) and pinnate species as $S$. fraxinifolium (group 2) provides evidence that the limits between these groups are weak.

\section{Materials and Methods}

Studies on the altitudinal variation as results of climate change in the ferns of the Río Macho Biological Station and surroundings, have served to discover this new nothotaxon that was located on Río Macho Biological Station, Orosi, Cartago. Its morphology obviously intermediate between Serpocaulon fraxinifolium (Jacq.) A.R. Sm. (A. Rojas 12347, CR) and S. loriceum L. (A. Rojas 12349, CR) highlighted the attention, while the presence of both species in the same place and their reproduction only in a vegetative confirms its hybrid origin. The possible parents and the hybrid were then collected for further analysis. In the laboratory, the specimens were observed, and their characters measured and quantified with the help of a Motic Instruments brand binocular stereoscope, Model SMZ-171BLED and a Motic brand binocular microscope, model BA210E. The information generated served to generate the description and diagnosis of the new nothotaxon, as well as the analysis and comparative table of this with its parents. Also, the spores of the hybrid were photographed. The correct use of scientific 
name and authors is according with International Plant Name Index.

The new nothospecies was located only in Río Macho over El Llano reservoir, a regenerated forest with about 50 years of recovery. The locality corresponds with a vegetation of evergreen montane tropical forest and climate of subtropical very humid forest.

The examined specimens were deposited in the following herbaria $\mathrm{CR}, \mathrm{K}, \mathrm{MO}$ (acronyms following Thiers [12]. To ensure the correct application names, original type material or digital type images were examined as available (Jstor Global Plants (http://plants.jstor.org/)), and the new names were corroborated with International Plant Name Index (http://www.ipni.org/ipni/plantnamesearchpage.do).

\section{Results}

\subsection{Taxonomy}

Here is described the new nothotaxon.

\subsubsection{Serpocaulon xorosiense A. Rojas, nothosp. nov. (Figure 1(B),} Figure 2(C), Figure 2(D), Figure 3(C), Figure 3(D) and Figure 4)

1) Type. COSTA RICA. Cartago: Paraíso, Orosi, Río Macho Biological Station, trail over El Llano reservoir, $9^{\circ} 45^{\prime} 51^{\prime \prime N}, 83^{\circ} 51^{\prime} 47^{\prime \prime} \mathrm{W}, 1700 \mathrm{~m}, 8$ Oct 2020, A. Rojas 12348 (Holotype: CR; Isotypes: $\mathrm{K}, \mathrm{MO}$ ).

2) Diagnoses. The new hybrid differs from Serpocaulon fraxinifolium by having rhizome scales that are relatively smaller and moderately less dense with dark brown central portions and narrower pale margins; blades that are 1-pinnate basally to pinnatisect distally and relative narrower; pinnae that are sessile and deltate to deltate-lanceolate and the basal ones slightly reduced at base; fewer series of areoles and sori; and spores that are whitish, and a few collapsed. Also differs from $S$. loriceum because has rhizome scales that are smaller and

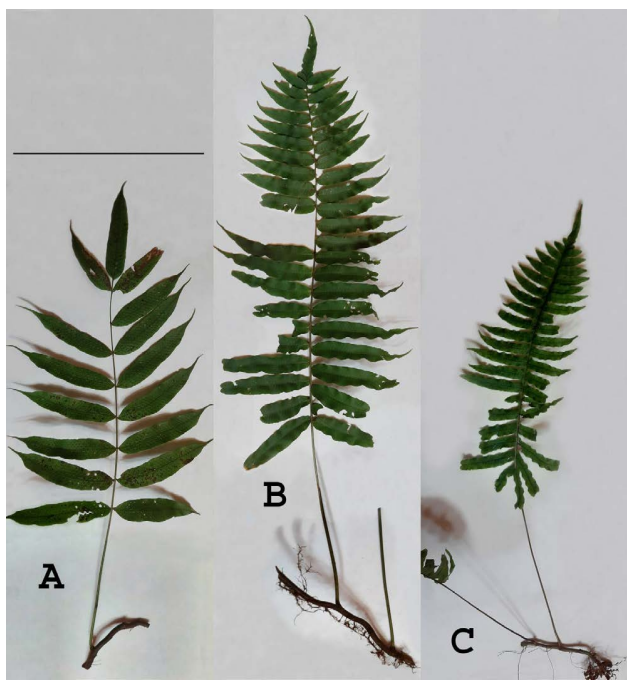

Figure 1. Habit of: A. Serpocaulon fraxinifolium (Jacq.) A.R. Sm. (A. Rojas 12347, CR). B. S. ×orosiense A. Rojas (A. Rojas 12348, CR). C. S. loriceum L. (A. Rojas 12349, CR). Scale $=25 \mathrm{~cm}$. 


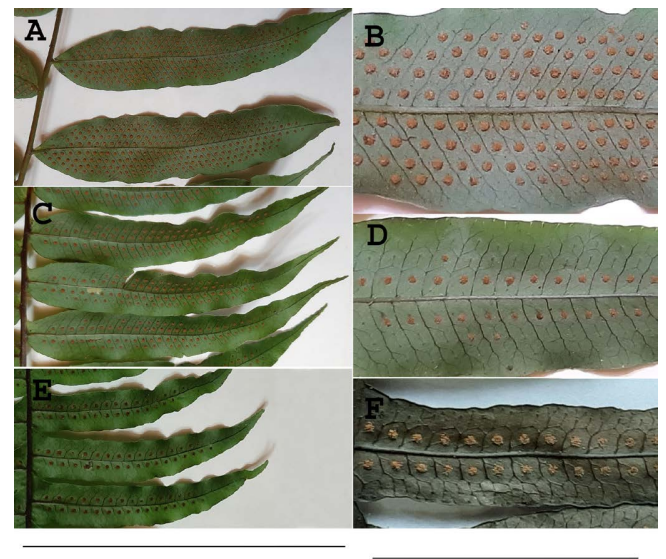

Figure 2. (A), (B). Serpocaulon fraxinifolium (Jacq.) A.R. Sm. (A. Rojas 12347, CR); (A). Blade detail; (B). Pinna detail. (C), (D). S. ×orosienseA. Rojas (A. Rojas 12348, CR); (C). Blade detail; (D). Pinna detail. (E), (F). S. loriceum L. (A. Rojas 12349, CR); (E). Blade detail; (F). Pinna detail. Left scale $=15 \mathrm{~cm}$. Right scale $=2.5 \mathrm{~cm}$.

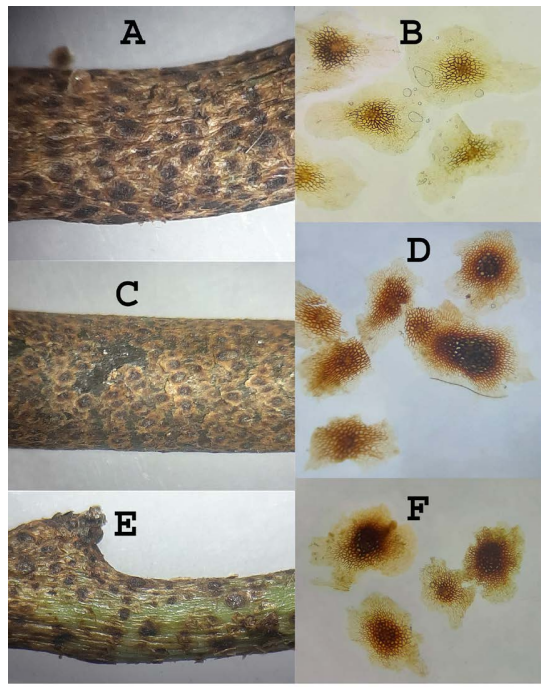

Figure 3. (A), (B). Serpocaulon fraxinifolium (Jacq.) A.R. Sm. (A. Rojas 12347, CR); (A). Rhizome detail. (B). Rhizome scales. (C), (D). S. xorosiense A. Rojas (A. Rojas 12348, CR); (C). Rhizome detail. (D). Rhizome scales. (E), (F). S. loriceum L. (A. Rojas 12349, CR); (E). Rhizome detail. (F). Rhizome scales. Left scale $=5 \mathrm{~mm}$. Right scale $=2 \mathrm{~mm}$.

less dense; longer fronds; blades that are relatively longer and pinnate basally to pinnatisect apically; pinnae that are broader; more series of areoles and sori; and spores that are whitish and regularly ellipsoidal or collapsed.

3) Description. Rhizome long creeping, $4-6 \mathrm{~mm}$ in diameter, non-pruinose, moderately to densely scaly; rhizome scales $1-2 \times 1-1.5 \mathrm{~mm}$, orbicular to ovate, clathrate, dark brown centrally, with pale-yellowish to light brown margin 


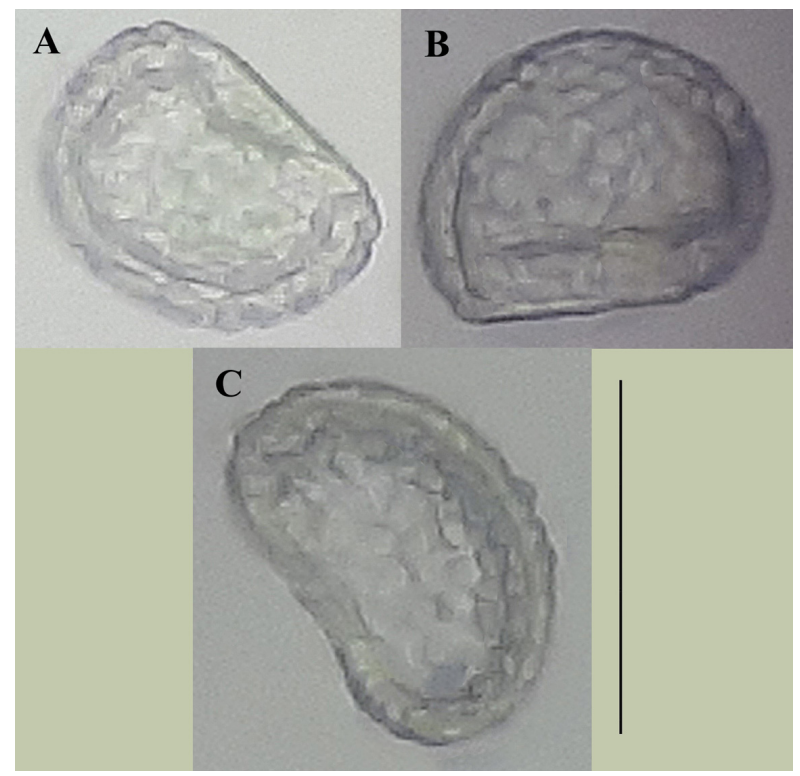

Figure 4. (A), (B), (C) Spores of Serpocaulon $\times$ orosiense A. Rojas ( $A$. Rojas 12348, CR). Scale $=50 \mu \mathrm{m}$.

$0.1-0.3 \mathrm{~mm}$, appressed, marginally entire to irregularly-lobulate, apically obtuse to rounded; fronds $71-82 \mathrm{~cm}$ long, separated by $4.0-7.5 \mathrm{~cm}$; stipe $21.6-25.2 \times$ $0.1-0.2 \mathrm{~cm}$, cylindrical, brown to dark brown, scaly, the scales $0.5-2.0 \mathrm{~mm}$ long, ovate, sparse, bicolorous with blackish center and pale yellow marginally; blade $46-72 \times 20-32 \mathrm{~cm}$, deltate-lanceolate to narrowly lanceolate, 1-pinnate basally to pinnatisect distally, basally truncate, apically subconform; pinnae (3-) 7 - $15.5 \times 0.9-) 1.5-2.5 \mathrm{~cm}, 22-28$ pairs, linear-lanceolate, sessile, straight to falcate, constricted at base to $5 \mathrm{~mm}$ in the basal pinnae, basal pinnae slightly deflexed, marginally entire; apicalpinnae $1.7-7.6 \times 0.7-1.5 \mathrm{~cm}$, smaller than lateral pinnae, with 1 - 2 basal lobules; rachis and costae brown to dark brown, sparsely scaly, scales similar to stipe scales; laminartissue glabrous; veins reticulate, forming 2 - 3 series of areoles between costa and margin; sori round, located in 1 - 2 lines between costa and margin; sporangia glabrous; spores bilateral, ellipsoidal, convex to slightly concave-convex, exospore prominently verrucate, translucent.

4) Etymology. The specific epithets refer to the place where it is known.

5) Other specimen examined. COSTA RICA. Cartago: Paraíso, Río Macho Biological Station, trail over El Llano reservoir, 9 $45^{\prime} 51^{\prime \prime N}, 83^{\circ} 51^{\prime} 47^{\prime \prime} \mathrm{W}, 1700 \mathrm{~m}$, 10 Oct 2019, A. Rojas, L. Barrantes \& F. Alfaro 12283 (CR, K, MO).

6) Comparative analysis. Serpocaulon $\times$ orosiense has characters that are intermediate between $S$. fraxinifolium and $S$. loriceumincluding size and density of rhizome scales, division and apex of blade, shape and width of pinnae, number of areolae, sori series, and color of spores (Table 1). The new hybrid differs from S. fraxinifoliumby having less dense ( $70 \%-90 \%$ covered vs. $90 \%-100 \%)$, smaller ( $1-2 \times 1.0-1.5 \mathrm{~mm}$ vs. (1.5-) $2-3 \times(1-) 1.5-2 \mathrm{~mm})$ rhizome scales, deltate-lanceolate to narrowly lanceolate (vs. ovate to deltate-lanceolate) and 
Table 1. Morphological comparison among Serpocaulon fraxinifolium (Jacq.) A.R. Sm., $S$. $\times$ orosiense A. Rojas and $S$. loriceum L.

\begin{tabular}{|c|c|c|c|}
\hline Character & S. fraxinifolium & S. xorosiense & S. loriceum \\
\hline $\begin{array}{l}\text { Rhizome diameter } \\
\qquad(\mathrm{mm})\end{array}$ & $3-6$ & $4-6$ & $3-5$ \\
\hline $\begin{array}{c}\text { Rhizome surface } \\
\text { covered by scales (\%) }\end{array}$ & $90-100$ & $70-90$ & $\begin{array}{c}50-80 \text { in the } \\
\text { area, } 10-30 \text { in } \\
\text { Caribbean islands }\end{array}$ \\
\hline $\begin{array}{l}\text { Size of rhizome } \\
\text { scales }(\mathrm{mm})\end{array}$ & $\begin{array}{l}(1.5-) 2-3 \times \\
(1-) 1.5-2\end{array}$ & $1-2 \times 1-1.5$ & $\begin{array}{c}0.7-1.5 \times 0.7- \\
1.0\end{array}$ \\
\hline Blade size $(\mathrm{cm})$ & $30-60(-75)$ & $46-72$ & $30-60(-85)$ \\
\hline Blade division & 1-pinnate throughout & $\begin{array}{l}\text { 1-pinnate basally to } \\
\text { pinnatisect distally }\end{array}$ & $\begin{array}{l}\text { Pinnatisect } \\
\text { throughout }\end{array}$ \\
\hline Blade shape & $\begin{array}{c}\text { ovate to } \\
\text { deltate-lanceolate }\end{array}$ & $\begin{array}{c}\text { deltate-lanceolate } \\
\text { to narrowly lanceolate }\end{array}$ & $\begin{array}{c}\text { deltate-lanceolate } \\
\text { to lanceolate }\end{array}$ \\
\hline Blade apex & conform & subconform & pinnatifid \\
\hline Pinnae pairs & (4-) $7-15$ & $22-28$ & $10-22$ \\
\hline Pinnae shape & lanceolate to elliptic & linear-lanceolate & linear-lanceolate \\
\hline Pinnae broad $(\mathrm{cm})$ & (1-) $2.5-3.5$ & $(0.9-) 1.5-2.5$ & $0.8-1.5(-2.0)$ \\
\hline Pinnae apex & cuspidate & acuminate & acute \\
\hline $\begin{array}{l}\text { Number of areolar } \\
\text { series with a free } \\
\text { veinlet included }\end{array}$ & $4-5$ & $2-3$ & $1-2$ \\
\hline Number of sori series & $3-5$ & $1-2$ & 1 \\
\hline Color of spores & yellow & whitish & yellow \\
\hline Spore shape & ellipsoidal & $\begin{array}{l}\text { ellipsoidal or } \\
\text { collapsed }\end{array}$ & ellipsoidal \\
\hline
\end{tabular}

1-pinnate basally to pinnatisect distally (vs. 1-pinnate throughout) blade divisions, subconform (vs. conform) blade apex, relatively narrower ((0.9-) 1.5 - 2.5 cm broad vs. (1-) $2.5-3.5 \mathrm{~cm}$ ), linear-lanceolate (lanceolate to elliptic), sessile (vs. free), more pairs (22 - 28 vs. (4-) 7 - 15) pinnae and with acuminate (vs. cuspidate) apex, fewer (2 - 3 vs. 4 - 5) series of areoles and fewer ((1-) 2 vs. 3 - 5) sori series, and whitish (vs. yellow) and ellipsoidal to collapsed (vs. ellipsoidal) spores (Table 1 ). The new hybrid also differs from $S$. loriceum by its relative broader (4 - $6 \mathrm{~mm}$ vs. 3 - 5) rhizome, bigger ( $1-2 \times 1.0-1.5 \mathrm{~mm}$ vs. $0.7-1.5 \times$ $0.7-1.0 \mathrm{~mm})$ and more dense ( $70 \%-90 \%$ covering the rhizome vs. $50 \%-80 \%$ in the area, $10 \%-30 \%$ in Caribbean islands) rhizome scales, 1-pinnate basally to pinnatisect distally (vs. pinnatisect throughout) blade divisions, subconform (vs. pinnatifid) blade apex, relatively broader ((0.9-) $1.5-2.5 \mathrm{~cm}$ vs. $0.8-1.5(-2.0)$ $\mathrm{cm}$ ) pinnae and with acuminate (vs. acute) apex, relative fewer (2 - 3 vs. 1 - 2) series of areoles and fewer (1 - 2 vs. 1) sori series, and whitish (vs. yellow) and el- 
lipsoidal to collapsed (vs. ellipsoidal) spores (Figures 1-4, Table 1).

\section{Discussion}

The type specimen ( $A$. Rojas 12348, CR, K, MO, USJ) was collected along with Serpocaulon fraxinifolium ( $A$. Rojas 12347, CR, K, MO) and S. loriceum (A. Rojas 12349, CR, K, MO) suggesting that it is hybrid between these two species. The hybrid and putative progenitors were growing as epiphytes at a height of cero to two meters in trees located between secondary forest. This area is characterized by approximately $2500-3800 \mathrm{~mm}$ of rainfall annually, is often shrouded in fog and temperatures between $13^{\circ} \mathrm{C}$ and $25^{\circ} \mathrm{C}$.

The hybrid Serpocaulon $\times$ orosiense has intermediate morphological characters between the putative parents $S$. fraxinifolium and $S$. loriceum, it does show two additive characters with longer fronds probably due to hybrid vigor and scally stipe and costa. Besides the fact that putative parents live in the same habitat, is the second hybrid discovered between pinnatisect and pinnate species, it suggests that are closely related species that can hybridize, and the division degree not is enough from a genetic distancing.

The Serpocaulon loriceum complex is not yet very clear, since in Costa Rica most specimens have very large scales with respect to the type material of the species, there are even two entities, one of them with intermediate-sized scales that cover more than $50 \%$ of the rhizome surface, many pairs of pinnae and grow between 600 and $1800 \mathrm{~m}$, which probably correspond to the entity of Polypodium beyerianum Rosenst., Repert. Spec. Nov. Regni Veg. 22 (606 - 608): 17. 1925. Lectotype: Costa Rica, Cartago, Turrialba, $650 \mathrm{~m}$, A. Brade \& C. Brade 21 (S(photo, US); isolectotypes: B!, NY!, UC!, US!), designated by Lellinger, Proc. Biol. Soc. Wash. 98 (2): 387 (1985). The second entity grows between 2000 - 3000 $\mathrm{m}$ and has the biggest rhizome scales of the group covering approximately $90 \%$ $100 \%$ of the rhizome, but has few pinnae pairs as the typical $S$. loriceum.

Spore abortion is a key character that provides evidence of hybridization (Moran 2004) [13], however, in this hybrid the spores are normal and well developed but whitish-translucent, according to the morphological characters for the spores of Serpocaulon genus proposed by Coelho \& Steves [5]. The pattern of normal spores was found in two more Serpocaulon hybrids from Colombia and Brazil [6] [8]. This suggests that a hybrid can be considered fertile or sterile and the shape of the spores have to be examined carefully, along with germination trials to determine hybrid fertility [9].

Further research on fern hybridization and it contributions to reticulate evolution has to be done, especially in tropical ecosystems where many hybrids are still unknown and hybrid origin species through polyploidy might be more frequent than considered previously [9].

\section{Acknowledgements}

Thanks to Daniel Rueda, ex-vicerector of research, who through Environmental 
Observatory of National University financing this project, to Costa Rican Electricity Institute (ICE in Spanish) who authorized this work in their property. Also thanks to anonymous reviewers for their helpful suggestions.

\section{Conflicts of Interest}

The authors declare no conflicts of interest.

\section{References}

[1] Smith, A.R., Kreier, H.P., Haufler, C.H., Ranker, T.A. and Schneider, H. (2006) Serpocaulon (Polypodiaceae), a New Genus Segregated from Polypodium. Taxon, 55, 919-930. https://doi.org/10.2307/25065686

[2] Rödl-Linder, G. (1990) A Monograph of the Fern Genus Goniophlebium (Polypodiaceae). Blumea, 34, 277-343.

[3] Schneider, H., Smith, A.R., Cranfill, R., Hildebrand, T.E., Haufler, C.H. and Ranker, T.A. (2004) Unraveling Thephylogeny of Polygrammoid Ferns (Polypodiaceae and Grammitidaceae): Exploring Aspects of the Diversification of Epiphytic Plants. Molecular Phylogenetics and Evolution, 31, 1041-1063. https://doi.org/10.1016/j.ympev.2003.09.018

[4] Lloyd, R.M. (1969) Occurrence of a Winged Perispore in a New World Species of Polypodium. Brittonia, 21, 80-82. https://doi.org/10.2307/2805661

[5] Coelho, C.B. and Esteves, L.M. (2011) Spore Morphology of Serpocaulon A.R. Sm. and Related Taxa from Brazil (Polypodiaceae). Grana, 50, 165-181. https://doi.org/10.1080/00173134.2011.614727

[6] Ramírez-Valencia, V., Sanín, D. and Pardo-Trujillo, A. (2013) Análisis morfológico de las esporas de Serpocaulon (Polypodiaceae) de la Cordillera Central de Colombia. Caldasia, 35, 177-197.

[7] Sanín, D. (2006) Serpocaulon A.R. Sm. (Polypodiaceae L.), Una revisión al género de helechos con forma de serpiente. Revista Universidad de Caldas, 89-103.

[8] Schwartsburd, P.B. and Smith, A.R. (2013) Novelties in Serpocaulon (Polypodiaceae). Journal of the Botanical Research Institute of Texas, 7, 85-93.

[9] Rojas-Alvarado, A.F. and Chaves-Fallas, J.M. (2013) A New Hybrid of Serpocaulon (Polypodiaceae) from Costa Rica. American Fern Journal, 103, 175-181. https://doi.org/10.1640/0002-8444-103.3.175

[10] Sanín, D. and Torrez, V. (2014) Serpocaulon $x$ manizalense. A New Hybrid between Simple and Pinnate-Leaved Species of Serpocaulon (Polypodiaceae) from Colombia. Blumea, 59, 123-130. https://doi.org/10.3767/000651914X685375

[11] Chaves-Fallas, J.M., Moran, R.C. and Oviedo-Brenes, F. (2015) Serpocaulon x rojasianum (Polypodiaceae): A New Fern Hybrid from Costa Rica. Brittonia. https://doi.org/10.1007/s12228-015-9368-2

[12] Thiers, B. (2016) Index Herbariorum: A Global Directory of Public Herbaria and Associated Staff. New York Botanical Garden's Virtual Herbarium. http://sweetgum.nybg.org/science/ih/

[13] Moran, R.C. (2004) A Natural History of Ferns. Timber Press, Portland. 